\title{
Nickel Supported on Mesoporous Zirconium Oxide by Atomic Layer Deposition: Initial Fixed-Bed Reactor Study
}

\author{
Pauline Voigt $^{1,2} \cdot$ Eero Haimi $^{1}$ D $\cdot$ Jouko Lahtinen $^{3}$ (D) $\cdot$ You Wayne Cheah ${ }^{1,4} \cdot$ Eveliina Mäkelä $^{1}$ (D) Tiia Viinikainen $^{1}$ (D) \\ Riikka L. Puurunen ${ }^{1}$ (D)
}

Published online: 14 January 2019

(c) The Author(s) 2019

\begin{abstract}
Atomic layer deposition (ALD) is gaining attention as a catalyst preparation method able to produce metal (oxide, sulphide, etc.) nanoparticles of uniform size down to single atoms. This work reports our initial experiments to support nickel on mesoporous zirconia. Nickel (2,2,6,6-tetramethyl-3,5-heptanedionate) ${ }_{2}$ [Ni(thd) $)_{2}$ was reacted in a fixed-bed ALD reactor with zirconia, characterised with BET surface area of $72 \mathrm{~m}^{2} / \mathrm{g}$ and mean pore size of $14 \mathrm{~nm}$. According to X-ray fluorescence measurements, the average nickel loading on the top part of the support bed was on the order of 1 wt $\%$, corresponding to circa one nickel atom per square nanometre. Cross-sectional scanning electron microscopy combined with energy-dispersive spectroscopy confirmed that in the top part of the fixed support bed, nickel was distributed throughout the zirconia particles. $\mathrm{X}$-ray photoelectron spectroscopy indicated the nickel oxidation state to be two. Organic thd ligands remained complete on the surface after the $\mathrm{Ni}$ (thd) $)_{2}$ reaction with zirconia, as followed with diffuse reflectance infrared Fourier transform spectroscopy. The ligands could be fully removed by oxidation at $400{ }^{\circ} \mathrm{C}$. These initial results indicate that nickel catalysts on zirconia can likely be made by ALD. Before catalytic testing, in addition to increasing the nickel loading by repeated ALD cycles, optimization of the process parameters is required to ensure uniform distribution of nickel throughout the support bed and within the zirconia particles.
\end{abstract}

Keywords Atomic layer deposition $\cdot$ Zirconia $\cdot$ Nickel $\cdot$ Catalyst $\cdot$ Ligand removal $\cdot$ Particles

\section{Introduction}

Atomic layer deposition (ALD) is a thin film growth method that allows the preparation of uniform inorganic material layers on arbitrarily complex three-dimensional structures. The three-dimensional uniformity, also termed "conformality," is a consequence of the systematic use of repeated, selfterminating (saturating, irreversible), separated gas-solid

Riikka L. Puurunen

riikka.puurunen@aalto.fi

1 Department of Chemical and Metallurgical Engineering, Aalto University School of Chemical Engineering, Espoo, P.O. Box 16100, 00076 Aalto, Finland

2 Institute for Inorganic Chemistry I, Technische Universität Dresden, Bergstraße 66, 01069 Dresden, Germany

3 Department of Applied Physics, Aalto University School of Science, P.O. Box 15100, 00076 Aalto, Finland

4 Faculty of Science and Engineering, Åbo Akademi University, 20500 Turku, Finland reactions of at least two compatible compounds [1-6]. While the principles of ALD were formulated already in the 1960s and 1970s, independently twice [7-14], it was in the 1990s that ALD was promoted as a tool for nanotechnology [15] and during the 2000s that ALD has enabled the continuation of Moore's law of transistor miniaturisation [16]. By the end of 2010, over 700 two-reactant ALD processes had been developed [17]. The Finnish inventor of ALD, Dr. Tuomo Suntola, received the prestigious Millennium Technology Prize in 2018 [18].

ALD can coat conformally porous high-surface-area catalyst supports by catalytically active materials. The first reports of the use of ALD for preparing supported heterogeneous catalysts are from the Soviet Union in the early 1970s, typically reported under the name "molecular layering" [12, 19-24]. In 1990s, there was a strong industry-driven effort for ALD for catalysis in Finland; the technique was then called "atomic layer epitaxy" [11, 25-32]. Interest in ALD for the preparation of supported heterogeneous catalysts has again been increasing during the past decade [33-39]. The 
current interest in ALD is based for example in the ability of ALD to prepare (close to) monodisperse metal particles; to make overcoatings to temper the activity of highly active but non-selective sites; and to prepare single-atom catalysts. The solvent-free nature of ALD is generally regarded an environmental advantage, and scaling up the catalyst preparation should be feasible.

Various reactor designs can be used for coating particles by ALD. Many of the early ALD catalyst works in the Soviet Union and Finland employed fixed-bed reactors [12, 24, 31]; fixed-bed reactors have recently re-gained interest [37]. Also fluidised bed [40-42] and rotary bed [43, 44] reactors have been used. Thanks to the advances on ALD in the field of microelectronics, many groups have recently used a reactor set-up where a tray of powder is placed in a reactor optimised for thin film growth [34]. Whatever the reactor type, the strength of ALD is best employed when the whole particle bed is coated with a uniform, conformal material layer. Attainment of saturation is not self-evident $[39,45]$; conformality in extreme aspect ratios needs process tuning and should be verified.

Nickel is a well known hydrogenation catalyst. Supported nickel catalysts were among the first ALD catalysts studied in Finland in the 1990s, with focus on toluene hydrogenation $[28,29]$. More recently, nickel catalysts have received attention for example in biomass gasification, not only because of their low price compared to noble metals, but also because they are highly active in tar cracking and reforming [46]. Nickel can be used for $\mathrm{CO}_{2}$ hydrogenation on silica-supported catalysts [47] and aqueous phase reforming of alcohols on zirconia containing supports [48]. In general, $\mathrm{ZrO}_{2}$ is considered as an attractive catalyst support due to its high thermal stability and amphoteric nature [49].

This work reports an initial study to prepare nickel catalysts on a mesoporous zirconia support by ALD cycles. We used $\mathrm{Ni}$ (thd) ${ }_{2}$ (thd = 2,2,6,6-tetramethyl-3,5-heptanedionate), a traditional ALD reactant [50-53], as the nickel source; and air as the oxygen source. To our best knowledge, this work is the first to report the ALD modification of mesoporous zirconia with nickel.

\section{Experimental}

\subsection{Materials}

The precursor Ni-bis-2,2,6,6-tetramethyl-heptane3,5-dionate $\left(\mathrm{Ni}(\text { thd })_{2}\right.$ ) was synthesised from nickel(II) acetate tetrahydrate (J.T. Baker Chemical, >98\%) and 2,2,6,6,-Tetramethyl-3,5-heptanedione (Tokio Chemical Industrie Co., > 97\%) according to literature methods $[53,54]$ and purified by sublimation under vacuum before use. Mesoporous zirconium oxide (Saint-Gobain Norpro, monoclinic $<0.2 \mathrm{wt} \% \mathrm{SiO}_{2}$ ) was crushed and sieved to 250-450 $\mu \mathrm{m}$ particles, calcined in synthetic air (purity 5.0, Oy AGA Ab) at $600{ }^{\circ} \mathrm{C}$ for $10 \mathrm{~h}$ and stored in an desiccator.

\section{$2.2 \mathrm{~N}_{2}$ Physisorption}

Nitrogen physisorption isotherms were measured at isothermal conditions in liquid nitrogen $(77 \mathrm{~K})$ using a Thermo Fisher Surfer equipment. The fresh, $600{ }^{\circ} \mathrm{C}$ heattreated zirconia support $(0.24 \mathrm{~g})$ was weighted in a quartz tube and evacuated at $350{ }^{\circ} \mathrm{C}$ for $3 \mathrm{~h}$ (heating ramp $5{ }^{\circ} \mathrm{C} /$ $\min$ ) prior to the measurement. Specific surface area was calculated from the adsorption isotherm according to the Brunauer-Emmett-Teller (BET) theory using the relative pressure $p / p^{0}$ range of $0.2-0.4$ [55]. Pore size distribution, mean pore diameter and total pore volume were calculated using the Barrett-Joyner-Halenda (BJH) method [56].

\subsection{ALD Procedure}

The experiments were carried out using an F-120 flow-type ALD reactor, modified to accommodate a porous high-surface-area materials in a fixed bed (ASM Microchemistry Ltd., Finland). The reactor and procedure were similar as described e.g. by Haukka et al. [31]. Schematic illustration of the fixed particle bed is shown in Fig. 1. The reaction chamber for powders (diameter $2 \mathrm{~cm}$ ) was used with the associated filter to hold up to ca. $5 \mathrm{~g}$ of support. The particle bed height was over one centimetre (accurate height not measured). The $\mathrm{Ni}$ (thd $)_{2}$ reactant was placed in an open glass boat within the reactor and sublimated at $140{ }^{\circ} \mathrm{C}$, operated under a moderate vacuum of 0.6-4 mbar (pressure measured after the support bed). Nitrogen ( $>99.99999 \%$, generated

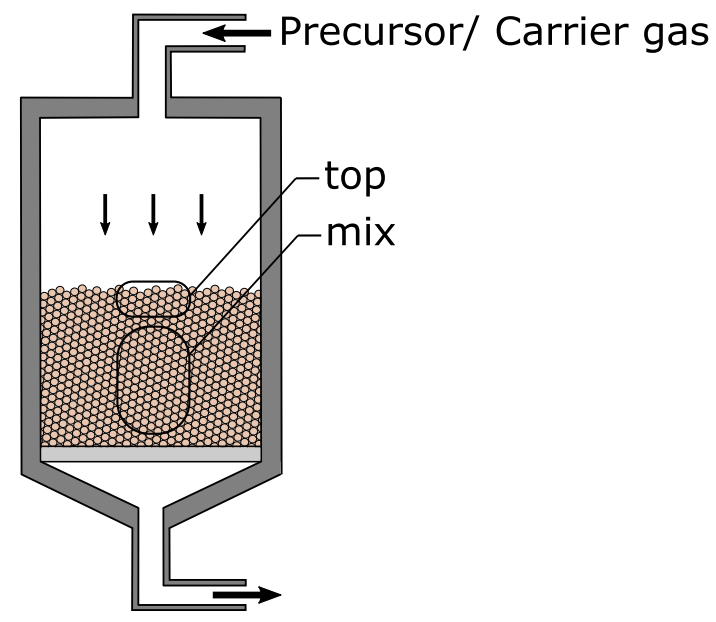

Fig. 1 A schematic illustration of the fixed-bed F-120 ALD reaction chamber. Samples were separately taken from the top of the particle bed and mixing the rest of the material as one sample 
with a Parker HPN2-5000 from air, with less than $10 \mathrm{ppm}$ of oxygen) was used as a carrier and purging gas, with constant flow rate of $400 \mathrm{sccm}$. The support was stabilised at $400{ }^{\circ} \mathrm{C}$ for $3 \mathrm{~h}$ in a stream of nitrogen. After this, the temperature was stabilised to the desired reaction temperature $\left(200{ }^{\circ} \mathrm{C}\right)$ and the reactant vapour was led downwards through the fixed support bed for $3 \mathrm{~h}$. After the reaction, the sample was purged with nitrogen at the reaction temperature for $2 \mathrm{~h}$. At the end of the run, the reactor was cooled in nitrogen flow close to room temperature before unloading. Samples were taken from the top part of the support bed and mixing the rest of the material as one sample. The samples were stored in a desiccator.

\subsection{X-ray Fluorescence}

The chemical composition and nickel loading of the prepared materials were measured semiquantitatively by X-ray fluorescence (XRF) using a PANalytical AxiosMax Wavelength Dispersive X-ray Fluorescence Spectrometer (WD$\mathrm{XRF})$. The device was equipped with a scintillation detector and a rhodium tube, which operated at $60 \mathrm{kV}$ with a current of $50 \mathrm{~mA}$. The samples $(100-500 \mathrm{mg})$ in powder form were placed on a supporting thin film using XRF sample cup (32 mm width).

\subsection{X-ray Photoelectron Spectroscopy}

The X-ray photoelectron spectroscopy (XPS) measurements were made using Kratos Axis Ultra system, equipped with a monochromatic AlK $\alpha \mathrm{X}$-ray source. All measurements were performed with $0.3 \mathrm{~mm} \times 0.7 \mathrm{~mm}$ analysis area and the charge neutraliser on. A wide scan was performed with $80 \mathrm{eV}$ pass energy and $1 \mathrm{eV}$ energy step. High resolution scans were performed with $20 \mathrm{eV}$ pass energy, $0.1 \mathrm{eV}$ steps size for $5 \mathrm{~min}$ for the $\mathrm{C} 1 \mathrm{~s}, \mathrm{Zr} 3 \mathrm{~d}$ and $\mathrm{O} 1 \mathrm{~s}$ and for $20 \mathrm{~min}$ for $\mathrm{Ni} 2 \mathrm{p}$. The energy calibration was made using the adventitious carbon $\mathrm{C} 1 \mathrm{~s}$ component at $284.8 \mathrm{eV}$. All deconvolutions were made with CasaXPS using GL(30) peaks (product of $30 \%$ Lorenztian and 70\% Gaussian). Information depth in XPS is roughly ten atomic layers.

\subsection{Scanning Electron Microscopy and Energy-Dispersive X-ray Spectrometry}

Scanning electron microscopy (SEM) and energy-dispersive $\mathrm{X}$-ray spectrometry (EDS) examination was carried out using Tescan Mira3 scanning electron microscope fitted with a Thermo Scientific energy-dispersive X-ray spectrometer. The EDS system was equipped with silicon drift detector (SDD). In sample preparation, mesoporous $\mathrm{Ni}$ (thd $)_{2}$-modified zirconia particles were mounted in epoxy resin utilizing vacuum impregnation. The cured mounts were ground and polished to expose cross-sections of the particles at the face of specimen. Subsequently, specimens were coated with carbon to prevent charging under the electron beam. In the SEM and EDS examination, electron accelerating voltage of $15 \mathrm{keV}$ was used. First, qualitative elemental analysis was performed to identify elements present in the specimen. Secondly, EDS line scans were performed across a selected $\mathrm{Ni}$ (thd $)_{2}$-modified zirconia particle. The length of the line was $600 \mu \mathrm{m}$ including 100 measurement points. Integration of 40 scans was utilised to improve precision of the measurement. Estimated detection limit of EDS is $0.1-0.3 \mathrm{wt} \%$.

\subsection{Thermogravimetric Analysis (TGA)}

The thermal properties of the nickel-modified zirconia were studied with ambient pressure thermogravimetric analysis (TGA) with the TGA Q500 (TA Instruments, USA). Heating rate of $10{ }^{\circ} \mathrm{C} / \mathrm{min}$ and temperature range of $30-600{ }^{\circ} \mathrm{C}$ were used. To reduce the amount of moisture, the sample was pre-heated ex situ for $2 \mathrm{~h}$ in air at $200{ }^{\circ} \mathrm{C}$ before the TGA analysis, and then quickly transferred into the TGA equipment. The TGA analysis was started with heating in nitrogen up to $200{ }^{\circ} \mathrm{C}$ and holding for $1 \mathrm{~h}$, after which the gas was changed to oxygen and heating was continued until $600{ }^{\circ} \mathrm{C}$.

\subsection{Diffuse Reflectance Infrared Fourier Transform (DRIFT) Spectroscopy}

Diffuse reflectance infrared Fourier transform (DRIFT) spectroscopy measurements were made to observe the vanishing of ligands during oxidation at elevated temperatures. Measurements were made with a Nicolet Nexus FTIR spectrometer using a Spectra-Tech in situ high temperature/high pressure chamber equipped with deuterated triglycine sulphate (DTGS) detector. The total gas flow was kept at $50 \mathrm{sccm}$ throughout the measurement. The sample-holder-cup was filled with $2 / 3$ pure zirconia (approx. $12 \mathrm{mg}$ ) at the bottom and $1 / 3 \mathrm{Ni}(\text { thd) })_{2}^{-}$ modified zirconia (approx. $5 \mathrm{mg}$ ) at the top. The applied background was the spectra of an aluminium mirror $\left(4 \mathrm{~cm}^{-1}\right.$ resolution, 200 scans) in the in situ cell under nitrogen flow.

First, the sample was pre-heated in the in situ cell in nitrogen $\left(\mathrm{N}_{2} 99.999 \%\right.$, Oy AGA Ab) at $200{ }^{\circ} \mathrm{C}$ for $3 \mathrm{~h}$, followed by cooling down to $30^{\circ} \mathrm{C}$. This was done to reduce moisture, which had been transferred within the sample to the in situ cell through ambient air. Next, the oxidation of the surface species was studied by feeding $10 \% \mathrm{O}_{2} / \mathrm{N}_{2}$ (synthetic air $99.99 \%$, Oy AGA $\mathrm{Ab}$ ) to the chamber at $30^{\circ} \mathrm{C}$ followed by increasing the temperature stepwise (steps of $25^{\circ} \mathrm{C}$ ) to $500{ }^{\circ} \mathrm{C}$. During the stepwise heating of the sample, spectra $\left(4 \mathrm{~cm}^{-1}\right.$ resolution, wavenumber range $4000-1000 \mathrm{~cm}^{-1}, 100$ scans) were recorded every $25^{\circ} \mathrm{C}$, i.e., approximately every $4 \mathrm{~min}$. 


\section{Results and Discussion}

\subsection{Porosity Characterization of the Support}

The porosity of the zirconia support heat-treated at $600{ }^{\circ} \mathrm{C}$ for $10 \mathrm{~h}$ in synthetic air was investigated through nitrogen physisorption. The $\mathrm{N}_{2}$ adsorption and desorption isotherms, shown in Fig. 2a, present hysteresis typical for a mesoporous structure [57]. The BET surface area extracted from the desorption isotherm was $72 \mathrm{~m}^{2} / \mathrm{g}$ and the total pore volume $0.27 \mathrm{~cm}^{3} / \mathrm{g}$. The BJH pore size distribution is presented in Fig. $2 \mathrm{~b}$ and shows a mean pore diameter of $13.6 \mathrm{~nm}$.

\subsection{Modification of Zirconia with $\mathrm{Ni}(\mathrm{thd})_{2}$ by ALD}

The $\mathrm{Ni}(\text { thd })_{2}$ was evaporated at approximately $140{ }^{\circ} \mathrm{C}$ and led through a fixed bed of mesoporous zirconia stabilised at $200{ }^{\circ} \mathrm{C}$. After the modification and cooling down, samples were taken from the top part of the fixed bed and mixing the rest of the material as one sample (see Fig. 1). According to the semiquantitative XRF measurements, the nickel content in the bed was on the order of $1 \mathrm{wt} \%$, with the top sample containing more nickel than the mixed sample (this had $\sim 60 \%$ of top-part content). For ALD, where saturation of the surface with adsorbed species has taken place throughout, a constant nickel concentration would be expected throughout the support bed. Full saturation had thus not taken place yet.

After the run, some $\mathrm{Ni}(\text { thd })_{2}$ was seen in the low-temperature condense tube at the reactor outlet. As the support bed had not saturated throughout, this means that at the flow conditions used in this work, some $\mathrm{Ni}(\text { thd })_{2}$ passed

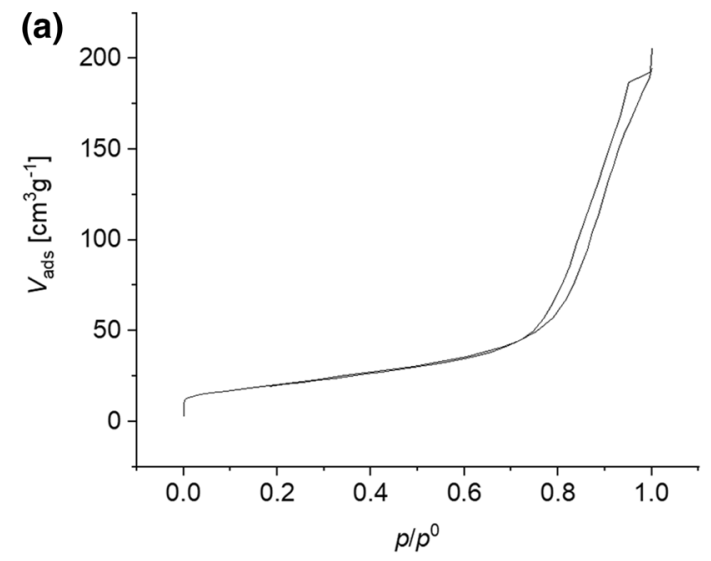

the bed unreacted and the reactant usage was therefore not optimally efficient.

To compare with other catalyst ALD studies and also with ALD growth on planar materials, it is of interest to convert the nickel loading from wt $\%$ to atoms per unit surface area, typically $\mathrm{nm}^{2}$ [3]. The nickel surface loading on zirconia with BET surface area of $72 \mathrm{~m}^{2} / \mathrm{g}$ was estimated to be on the order of $1 \mathrm{Ni} / \mathrm{nm}^{2}$.

For further characterization by XPS, SEM-EDS, TGA and DRIFT spectroscopy, a sample taken from the top part of the support bed was used.

\subsection{XPS}

The wide spectrum and high resolution spectra of $\mathrm{C} 1 \mathrm{~s}, \mathrm{Zr}$ $3 d, \mathrm{O} 1 \mathrm{~s}$ and $\mathrm{Ni} 2 \mathrm{p}$ regions are shown in Fig. 3. Based on the wide scan, the estimated $\mathrm{Ni}$ content of the surface layer was 2 at.\%. For the high resolution spectra we performed a deconvolution of the $\mathrm{C}$ 1s spectrum (Fig. 3a) to estimate the binding energy (BE) of the main peak identified as adventitious carbon in order to get a good BE reference. After fitting, the most intense peak was shifted to $284.84 \mathrm{eV}$ and all the other C-peaks as well as other spectra were corrected with the same offset. The other components visible in the $\mathrm{C}$ 1s spectrum correspond to different $\mathrm{C}-\mathrm{O}$-bonds normally visible after air exposure. The $\mathrm{Zr} 3 \mathrm{p}$ and $\mathrm{O} 1 \mathrm{~s}$ spectra shown in Fig. 3 are typical for $\mathrm{ZrO}_{2}$ with the $\mathrm{Zr} 3 \mathrm{~d} 5 / 2$ peak close to $182 \mathrm{eV}$ and the $\mathrm{O} 1 \mathrm{~s}$ peak close to $530 \mathrm{eV}$.

The Ni 2 p region shows the $2 \mathrm{p} 3 / 2$ peak at $855.5 \mathrm{eV}$ and the $2 \mathrm{p} 1 / 2$ peak at $873.2 \mathrm{eV}$. Both peaks have a satellite roughly $6 \mathrm{eV}$ above the main peak. We also measured pure $\mathrm{Ni}(\text { thd })_{2}$ for reference, and noticed that the shape of the spectrum is similar, although the intensities of the satellites compared to the main peak are higher in the $\mathrm{Ni}(\text { thd })_{2}$ modified zirconia samples. The satellite intensity in the $\mathrm{Ni}(\text { thd })_{2}$ increased when the material was left in air for one

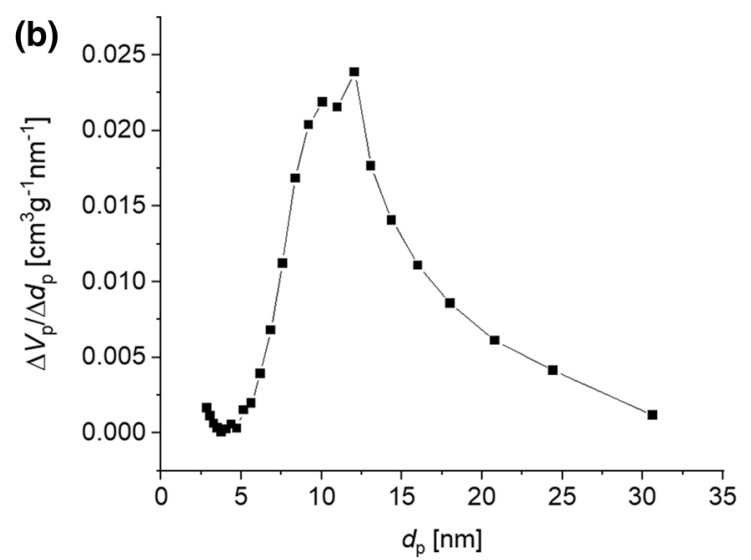

Fig. 2 Results of nitrogen adsorption and desorption isotherms of the zirconia support: a volume of $\mathrm{N}_{2}$ adsorbed $V_{\text {ads }}$ (per gram of sample) as function of the relative pressure of nitrogen $p / p^{0}$, and $\mathbf{b}$ pore size $\left(d_{\mathrm{p}}\right)$ distribution of the zirconia, as analysed with the BJH method 
Fig. 3 X-ray photoelectron spectra of $\mathrm{Ni}(\text { thd })_{2}$-modified zirconia: a C 1s, b Zr 3d, c $\mathrm{O} 1 \mathrm{~s}$ and $\mathbf{d} \mathrm{Ni} 2 \mathrm{p}$ regions, and e the corresponding wide energy spectrum. $\mathbf{d}$ shows for comparison also the spectrum of $\mathrm{Ni}(\text { thd })_{2}$ reference
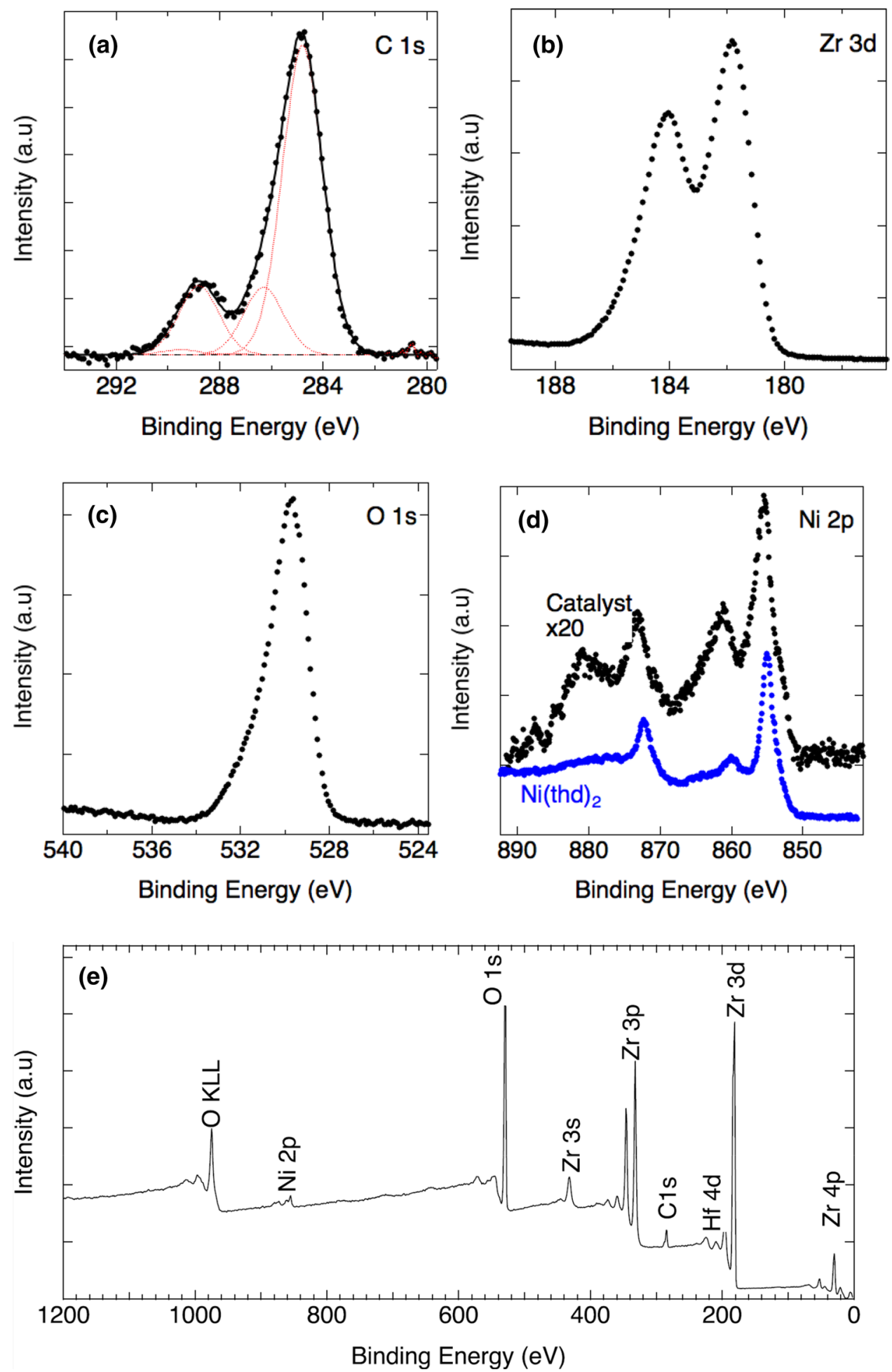

night (not shown). We expect this change is due to exposure to humidity. Deconvolution of the Ni spectrum was not performed, but we compared the $\mathrm{Ni}$ spectra against reference spectra of $\mathrm{NiO}$ and $\mathrm{Ni}(\mathrm{OH})_{2}$ [58]. $\mathrm{NiO}$ reference shows two components in the $2 \mathrm{p} 3 / 2$ peak around $855.5 \mathrm{eV}$ separated by $1.7 \mathrm{eV}$ not visible in our data. The $\mathrm{Ni}(\mathrm{OH})_{2}$ reference shows one main peak at $855.5 \mathrm{eV}$ and a satellite $6 \mathrm{eV}$ above that, resembling our data. However, the $\mathrm{Ni}(\mathrm{OH})_{2}$ peaks reported by [58] are not sufficient to reproduce our data. This indicates slightly different environment for $\mathrm{Ni}$ atoms than in $\mathrm{Ni}(\mathrm{OH})_{2}$ or $\mathrm{NiO}$ but their oxidation state seems to be two. 


\subsection{SEM-EDS}

Initial EDS results showed the presence of $\mathrm{Ni}$ in the studied sample. The results concerning Ni distribution across a zirconia particle are presented in Fig. 4. Figure 4a illustrates the position of EDS line scan on top of backscattered electron image (BSE) of the zirconia particle. Figure $4 \mathrm{~b}$ and $\mathrm{c}$ show measured $\mathrm{X}$-ray intensities as a function of distance along the line scan. The Fig. $4 \mathrm{~b}$ presents in principle both $\mathrm{Zr}$ and $\mathrm{Ni}$ intensities for $\mathrm{L}-$ and $\mathrm{K}$-lines, respectively. Intensities coming from $\mathrm{Ni}$ are several orders of magnitude lower than intensities coming from $\mathrm{Zr}$, however, and therefore not distinguishable in the figure. In Fig. $4 c$, the same results for $\mathrm{Ni}$ are presented using smaller intensity axis scaling. The measured X-ray intensities are proportional to the concentrations of $\mathrm{Zr}$ and $\mathrm{Ni}$, respectively. Despite background noise, $\mathrm{Ni}$ was detected in zirconia particles in trace element amount. Furthermore, Ni was observed to be distributed throughout the zirconia particle.

\subsection{TGA of Nickel-Modified Zirconia}

After reacting $\mathrm{Ni}$ (thd $)_{2}$ with zirconia, at least one thd ligand was expected to remain on the surface. To increase the nickel loading by repeating ALD cycles, the remaining ligands needs to be removed. This can be done with air at an elevated temperature.

As a pre-test to find the suitable temperature for removal of the organic thd ligands, TGA analysis was made for the nickel-modified zirconia; the results are shown in Fig. 5. Significant weight loss likely due to dehydration and/or dehydroxylation was observed especially up to $200{ }^{\circ} \mathrm{C}$, and to a small extent after that. An additional weight loss occurred at about $300-400{ }^{\circ} \mathrm{C}$, which can likely be attributed to removal of the organic thd ligands by oxidation. Some weight loss continued after $400{ }^{\circ} \mathrm{C}$.

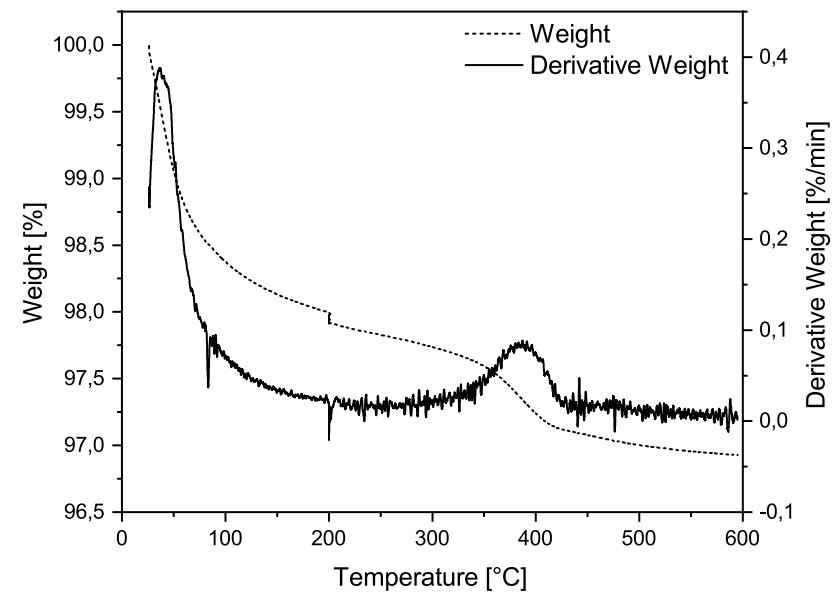

Fig. 5 TGA curve of $\mathrm{Ni}$ (thd) $)_{2}$-modified $\mathrm{ZrO}_{2}$, heated in $\mathrm{N}_{2}$ at $200{ }^{\circ} \mathrm{C}$ for $1 \mathrm{~h}$ to reduce moisture, continued by heating in $\mathrm{O}_{2}\left(200-600{ }^{\circ} \mathrm{C}\right)$ with a heating rate of $10^{\circ} \mathrm{C} / \mathrm{h}$

\subsection{DRIFT Spectroscopy Observation of Thd Ligand Removal in Air}

DRIFT spectroscopy was used to study how the thd ligands were attached to the zirconia support and for the removal of the thd ligands by oxygen during heating in air.

The zirconia support was measured as a reference and the spectrum at $30{ }^{\circ} \mathrm{C}$ was recorded after heating in $\mathrm{N}_{2}$ at $200^{\circ} \mathrm{C}$ for $2 \mathrm{~h}$ (spectrum A in Fig. 6). The spectrum showed peaks at $3776 \mathrm{~cm}^{-1}$ and $3671 \mathrm{~cm}^{-1}$, and a small shoulder between these two bands at $3734 \mathrm{~cm}^{-1}$. The peaks at $3776 \mathrm{~cm}^{-1}$ and $3671 \mathrm{~cm}^{-1}$ can be assigned to terminal and tribridged OH groups [59]. The small shoulder at $3734 \mathrm{~cm}^{-1}$ is likely indicating the existence of bibridged $\mathrm{OH}$ groups [59]. Small bands observed between 1600 and $1000 \mathrm{~cm}^{-1}$ can be assigned to residual carbonate groups trapped inside the zirconia bulk [60]. The spectrum of the zirconia support (spectrum A in Fig. 6) also showed moisture on the sample that was expected due to the pretreatment at low temperature (a)

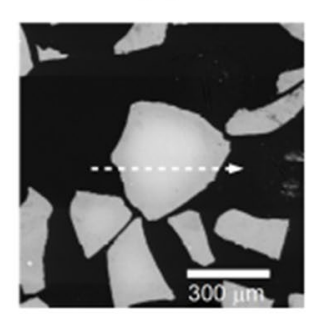

(b)

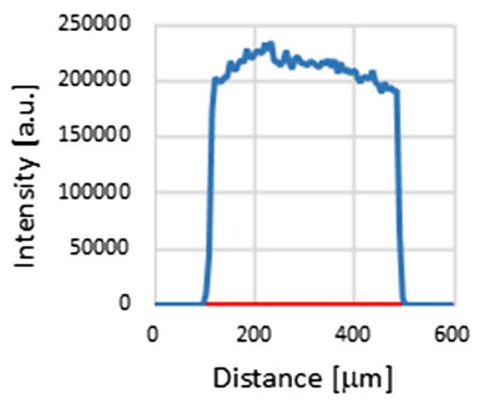

(c)

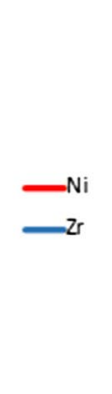

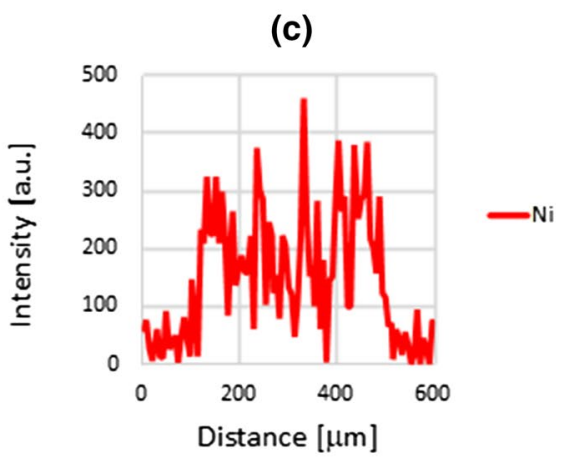

Fig. 4 SEM-EDS results: a Backscattered electron image of zirconia particle showing the position of EDS line scan. $\mathbf{b}$ The EDS line scan of a zirconia particle. $\mathbf{c}$ The EDS line scan of a zirconia particle with smaller intensity axis scaling 


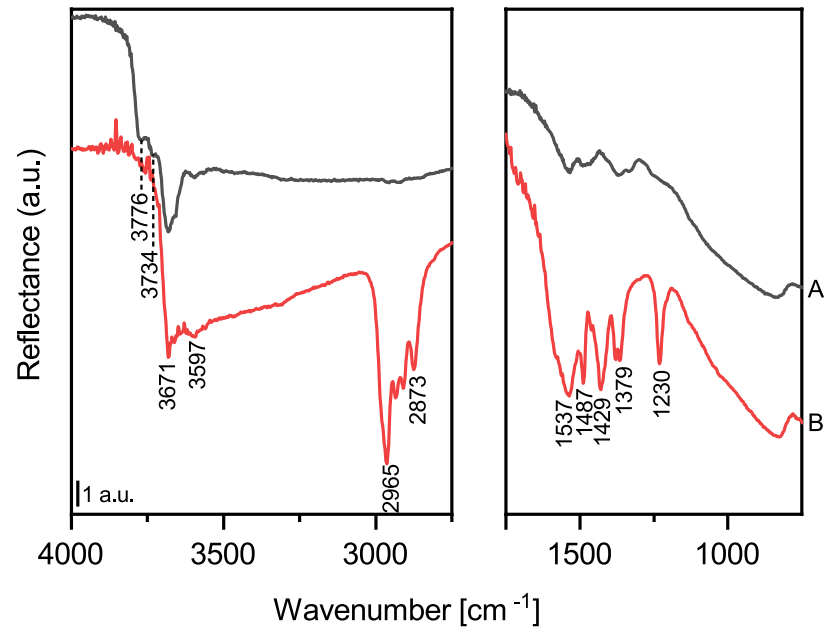

Fig. 6 DRIFT spectra of $\mathbf{a} \mathrm{ZrO}_{2}$ and $\mathbf{b} \mathrm{Ni}(\text { thd })_{2}$-modified zirconia at $30{ }^{\circ} \mathrm{C}$ after pre-heating at $200{ }^{\circ} \mathrm{C}$ for $2 \mathrm{~h}$ in $\mathrm{N}_{2}$. Spectra shifted vertically for clarity

$\left(200{ }^{\circ} \mathrm{C}\right)$. The $\mathrm{OH}$ groups have been reported to have more intense peaks when calcined at $600{ }^{\circ} \mathrm{C}$ for $2 \mathrm{~h}$ in air flow [59].

The spectrum of $\mathrm{Ni}$ (thd) ${ }_{2}$-modified zirconia (pretreated in $\mathrm{N}_{2}$ at $200{ }^{\circ} \mathrm{C}$ for $2 \mathrm{~h}$ and cooled down to $30^{\circ} \mathrm{C}$ ) showed several intense peaks (spectrum B in Fig. 6), indicating differences compared to the unmodified support (spectrum A in Fig. 6). The presence of adsorbed ligands on the nickel-modified zirconia is evidenced through the methyl group signals (C-H stretching and bending vibrations) at $2965-2873 \mathrm{~cm}^{-1}$ and $1429-1230 \mathrm{~cm}^{-1}[31,61]$, as well as through bands related to the thd ligand at $1600-1488 \mathrm{~cm}^{-1}(\mathrm{C}=\mathrm{C}$ and $\mathrm{C}=\mathrm{O}$ stretching vibrations) [31]. Compared to the spectrum of the zirconia support (spectrum A in Fig. 6), it can be seen that the terminal and bibridged $\mathrm{OH}$ groups (at 3776 and $3734 \mathrm{~cm}^{-1}$ ) have disappeared and the band for tribridged $\mathrm{OH}$ groups (at $3671 \mathrm{~cm}^{-1}$ ) has decreased in the $\mathrm{Ni}(\text { thd })_{2}$ reaction. The absence of terminal hydroxyl groups suggests that $\mathrm{Ni}(\text { thd })_{2}$ consumed them during the reaction with zirconia; the same likely took place with the bibridging $\mathrm{OH}$ groups. Similarly, in earlier works, it has been reported that $\mathrm{OH}$ groups of zirconia, especially the terminal $\mathrm{OH}$ groups, react with the precursor in the ALD reaction of $\mathrm{Cr}(\mathrm{acac})_{3}$ $($ acac $=$ acetylacetonate $)$ and zirconia support [62].

The DRIFT spectra measured during heating between 30 and $500{ }^{\circ} \mathrm{C}$ for the nickel-modified zirconia are shown in Fig. 7. The peaks assigned to the thd ligands stayed largely intact during heating in air up to $300{ }^{\circ} \mathrm{C}$. At $350{ }^{\circ} \mathrm{C}$, the $\mathrm{C}-\mathrm{H}$ bands (at 2873-2965 and 1230-1429 $\mathrm{cm}^{-1}$ ) and $\mathrm{C}-\mathrm{O}$ bands (at $1488-1600 \mathrm{~cm}^{-1}$ ) started to decrease in intensity and at $400{ }^{\circ} \mathrm{C}$ these bands disappeared. Thus, it can be concluded that thd ligands were completely decomposed via oxidation below $400{ }^{\circ} \mathrm{C}$. These results are in line with those observed

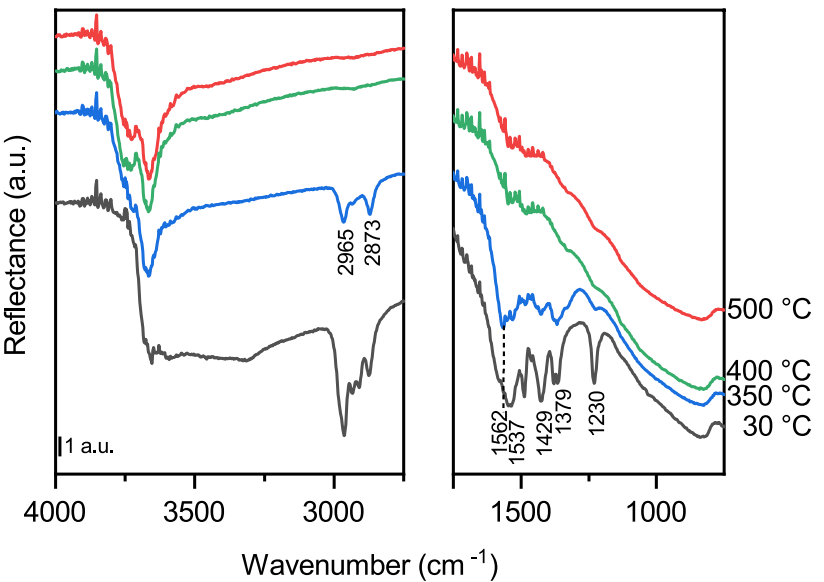

Fig. 7 DRIFT spectra of $\mathrm{Ni}$ (thd $)_{2}$-modified zirconia, heated $30-500{ }^{\circ} \mathrm{C}$ in $10 \% \mathrm{O}_{2} / \mathrm{N}_{2}$. Spectra have been collected with the sample at the indicated temperature $\left(30-500{ }^{\circ} \mathrm{C}\right)$, after initially pre-heating at $200{ }^{\circ} \mathrm{C}$ for $2 \mathrm{~h}$ and cooling again to $30{ }^{\circ} \mathrm{C}$ in $\mathrm{N}_{2}$ (see Fig. 6). Spectra shifted vertically for clarity

earlier for $\operatorname{Ir}(\mathrm{acac})_{3}$ and $\mathrm{Pt}(\mathrm{acac})_{2}$ on alumina support, where acac ligands were oxidised below $500{ }^{\circ} \mathrm{C}$ [63].

To summarize, DRIFT spectroscopy results showed that the reaction of $\mathrm{Ni}$ (thd) $)_{2}$ with the zirconia support brought out the expected thd ligands while consuming $\mathrm{OH}$ groups. These ligands can be decomposed and removed in the presence of oxygen by $400{ }^{\circ} \mathrm{C}$, thus completing the first ALD cycle. The effective removal of ligands by heating in oxygen is essential for the future use of nickel-modified zirconia as a catalyst since unremoved ligands would affect the activity of a catalyst.

\section{Conclusion}

This article reports our first efforts to support nickel on mesoporous high-surface-area zirconia by ALD for catalytic purposes. A nickel loading of approximately $1 \mathrm{wt} \%$ was obtained by the $\mathrm{Ni}$ (thd $)_{2}$ reaction at $200{ }^{\circ} \mathrm{C}$ using a commercial fixed-bed powder ALD reactor. The corresponding surface loading on zirconia (with BET surface area of $72 \mathrm{~m}^{2} / \mathrm{g}$ and mean pore diameter of $14 \mathrm{~nm}$ ) was on the order of $1 \mathrm{Ni} /$ $\mathrm{nm}^{2}$. Full saturation throughout the support bed was not yet attained in this initial work. According to XPS, all nickel had oxidation state two. According to SEM-EDS cross-sectional observation, at the top part of the fixed particle bed, nickel was observed throughout the zirconia particle. Organic thd ligands remained complete on the surface after the $\mathrm{Ni}$ (thd) $)_{2}$ reaction with zirconia, as followed with DRIFT spectroscopy. The first ALD cycle was completed by oxidation, which removed the remaining organic ligands at approximately $400{ }^{\circ} \mathrm{C}$ and re-created $\mathrm{OH}$ groups on the surface. 
To use the Ni/zirconia materials as catalysts, it is advisable to ensure full saturation throughout the support bed and within the zirconia particles. Further optimization work is needed to ensure saturation and increase the nickel loading before catalytic testing.

Acknowledgements Open access funding provided by Aalto University. This manuscript is partly based on the Berzelius Prize plenary lecture by R.L.P. at the Nordic Symposium on Catalysis, August 2018, Copenhagen, Denmark. The results have been reported in the M.Sc. thesis of P.V. at Technische Universität Dresden, supervised by Prof. Stefan Kaskel. Daniel Settipani is acknowledged for helping P.V. with the ALD practicalities, and Ilkka Välimaa for helping Y.W.C. with XRF. Dr. Yingnan Zhao is thanked for valuable insights on the DRIFT spectroscopy experiments. Information on early molecular layering references has been collectively gathered in the Virtual Project on the History of ALD. Y.W.C. thanks Ảbo Akademi University for the 2018 partial internship grant. This research has benefited from the Bioeconomy and RawMatTERS Finland (RAMI) research infrastructures at Aalto University and used facilities at OtaNano - Nanomicroscopy Center (Aalto-NMC).

OpenAccess This article is distributed under the terms of the Creative Commons Attribution 4.0 International License (http://creativeco mmons.org/licenses/by/4.0/), which permits unrestricted use, distribution, and reproduction in any medium, provided you give appropriate credit to the original author(s) and the source, provide a link to the Creative Commons license, and indicate if changes were made.

\section{References}

1. Suntola T (1989) Atomic layer epitaxy. Mater Sci Rep 4:261-312. https://doi.org/10.1016/S0920-2307(89)80006-4

2. Leskelä M, Ritala M (2002) Atomic layer deposition (ALD): from precursors to thin film structures. Thin Solid Films 409:138-146. https://doi.org/10.1016/S0040-6090(02)00117-7

3. Puurunen RL (2005) Surface chemistry of atomic layer deposition: a case study for the trimethylaluminum/water process. J Appl Phys 97:121301. https://doi.org/10.1063/1.1940727

4. George SM (2010) Atomic layer deposition: an overview. Chem Rev 110:111-131. https://doi.org/10.1021/cr900056b

5. Gao F, Arpiainen S, Puurunen RL (2015) Microscopic siliconbased lateral high-aspect-ratio structures for thin film conformality analysis. J Vac Sci Technol A 33:101601. https://doi. org/10.1116/1.4903941

6. Ylilammi M, Ylivaara OME, Puurunen RL (2018) Modeling growth kinetics of thin films made by atomic layer deposition in lateral high-aspect-ratio structures. J Appl Phys 123:205301. https ://doi.org/10.1063/1.5028178

7. Aleskovskii VB, Koltsov SI (1965) Some characteristics of molecular layering reactions. In: Abstract of Scientific and Technical Conference of the Leningrad Technological Institute by Lensovet (Goskhimizdat, Leningrad, 1965), pp 67-67 (in Russian)

8. Aleskovskii VB (1974) Chemistry and technology of solids. J Appl Chem USSR 47:2207-2217 [Zh Prikl Khim 47:2145-2157]

9. Suntola T, Antson J (1974) Patent FIN 52359 (29 November 1974); corresponds to U.S. patent 4058430 (25 November 1975)

10. Suntola T, Hyvärinen J (1985) Atomic layer epitaxy. Annu Rev Mater Sci 15:177-195
11. Puurunen RL (2014) A short history of Atomic Layer Deposition: Tuomo Suntola's Atomic Layer Epitaxy. Chem Vap Depos 20:332-344. https://doi.org/10.1002/cvde.201402012

12. Malygin AA, Drozd VE, Malkov AA, Smirnov VM (2015) From V. B. Aleskovskii's "Framework" hypothesis to the method of molecular layering/atomic layer deposition. Chem Vap Depos 21:216-240. https://doi.org/10.1002/cvde.201502013

13. Ahvenniemi E, Akbashev AR, Ali S, Bechelany M, Berdova M, Boyadjiev S, Cameron DC, Chen R, Chubarov M, Cremers V, Devi A, Drozd V, Elnikova L, Gottardi G, Grigoras K, Hausmann DM, Hwang CS, Jen SH, Kallio T, Kanervo J, Khmelnitskiy I, Kim DH, Klibanov L, Koshtyal Y, Krause AOI, Kuhs J, Kärkkänen I, Kääriäinen ML, Kääriäinen T, Lamagna L, Łapicki AA, Leskelä M, Lipsanen H, Lyytinen J, Malkov A, Malygin A, Mennad A, Militzer C, Molarius J, Norek M, Özgit-Akgün Ç, Panov M, Pedersen H, Piallat F, Popov G, Puurunen RL, Rampelberg G, Ras RHA, Rauwel E, Roozeboom F, Sajavaara T, Salami H, Savin H, Schneider N, Seidel TE, Sundqvist J, Suyatin DB, Törndahl T, Van Ommen JR, Wiemer C, Ylivaara OME, Yurkevich O (2017) Review article: recommended reading list of early publications on atomic layer deposition-outcome of the "Virtual Project on the History of ALD. J Vac Sci Technol A 25:010801. https://doi.org/10.1116/1.49713 89

14. Puurunen RL (2018) Learnings from an Open Science effort: Virtual Project on the History of ALD. ECS Trans 86(6):3-17. https://doi.org/10.1149/08606.0003ecst

15. Ritala M, Leskelä M (1999) Atomic layer epitaxy—a valuable tool for nanotechnology? Nanotechnology 10:19-24. https://doi. org/10.1088/0957-4484/10/1/005

16. Bohr MT, Chau RS, Ghani T, Mistry K (2007) The high-k solution. IEEE Spectr 44:29-35. https://doi.org/10.1109/MSPEC .2007 .4337663

17. Miikkulainen V, Leskelä M, Ritala M, Puurunen RL (2013) Crystallinity of inorganic films grown by atomic layer deposition: overview and general trends. J Appl Phys 113:021301. https://doi.org/10.1063/1.4757907

18. Technology Academy Finland, May 22, 2018 (2018) 2018 Millennium Technology Prize for Tuomo Suntola - Finnish physicist's innovation enables manufacture and development of information technology products. https://taf.fi/2018/05/22/2018millennium-technology-prize-for-tuomo-suntola-finnish-physi cists-innovation-enables-manufacture-and-development-of-infor mation-technology-products/. Accessed 29 June 2018

19. Koltsov SI, Smirnov VM, Aleskovskii VB (1970) Influence of the carrier on catalysts properties. Kinet Catal 11:835-841 (Kinet Katal 11:1013-1021)

20. Volkova AN, Malygin AA, Koltsov SI, Aleskovskii VB (1972) The method of synthesis of $\mathrm{Cr}(\mathrm{III})$ and $\mathrm{P}(\mathrm{V})$ oxide layers on the silicagel surface. USSR author's certificate patent 422446 (submitted 31 March 1972) (in Russian)

21. Malygin AA, Volkova AN, Koltsov SI, Aleskovskii VB (1972) The method of synthesis of vanadium oxide catalyst for the oxidation of organic compounds. USSR author's certificate patent 422447 (submitted 31 March 1972) (in Russian)

22. Koltsov SI, Smirnov VM, Aleskovskii VB (1973) Influence of carrier on the properties of catalyst. II. Kinet Katal 14:13001303 (in Russian)

23. Damyanov D, Mehandjiev D, Obretenov T (1975) Preparation of Chromium oxides on the surface of silica gel by the method of molecular deposition. IV. Catalytic properties. In: Proc. III Inter. Symp. Heterogeneous Catalysis-Varna, pp 191-195

24. Malygin AA, Malkov AA, Dubrovenskii SD (1996) Chap. 1.8 The chemical basis of surface modification technology of silica and alumina by molecular layering method. Stud Surf Sci Catal 99:213-236. https://doi.org/10.1016/S0167-2991(06)81022-0 
25. Suntola T, Lakomaa EL, Knuuttila H, Knuuttila P, Krause O, Lindfors S (1990) Process and apparatus for preparing heterogeneous catalysts, Jan 16, 1990, Patent F184562

26. Suntola T, Haukka S, Kytökivi A, Lakomaa EL, Lindblad M, Hietala J, Hokkanen H, Knuuttila H, Knuuttila P, Krause O, Lindfors LP (1991) Method for preparing heterogeneous catalysts of desired metal content, Jul 16, 1991, Patent F187892

27. Lakomaa EL (1994) Atomic layer epitaxy (ALE) on porous substrates. Appl Surf Sci 75:185-196. https://doi. org/10.1016/0169-4332(94)90158-9

28. Lindblad M, Lindfors LP, Suntola T (1994) Preparation of Ni/ $\mathrm{Al}_{2} \mathrm{O}_{3}$ catalysts from vapor phase by atomic layer epitaxy. Catal Lett 27:323-336. https://doi.org/10.1007/BF00813919

29. Jacobs JP, Lindfors LP, Reintjes JGH, Jylhä O, Brongersma HH (1994) The growth mechanism of nickel in the preparation of $\mathrm{Ni} / \mathrm{Al}_{2} \mathrm{O}_{3}$ catalysts studied by LEIS, XPS and catalytic activity. Catal Lett 25:315-324. https://doi.org/10.1007/BF00816311

30. Kytökivi A, Jacobs JP, Hakuli A, Meriläinen J, Brongersma HH (1996) Surface characteristics and activity of chromia/alumina catalysts prepared by atomic layer epitaxy. J Catal 162:190-197. https://doi.org/10.1006/jcat.1996.0276

31. Haukka S, Lakomaa EL, Suntola T (1999) Adsorption controlled preparation of heterogeneous catalysts. Stud Surf Sci Catal 120:715-750

32. Lakomaa EL, Lindblad M, Kytökivi A, Siro-Minkkinen H, Haukka S (2013) Catalyst processing development by atomic layer epitaxy (ALE). In: Catalysis in Finland-and exciting pathway, Suomen katalyysiseura. Otavan Kirjapaino Oy, Keuruu, pp 93-103

33. Sun S, Zhang G, Gauquelin N, Chen N, Zhou J, Yang S, Chen W, Meng X, Geng D, Banis MN, Li R, Ye S, Knights S, Botton GA, Sham TK, Sun X (2013) Single-atom catalysis using Pt/ graphene achieved through atomic layer deposition. Sci Rep 3:1775. https://doi.org/10.1038/srep01775

34. O'Neill BJ, Jackson DHK, Lee J, Canlas C, Stair PC, Marshall CL, Elam JW, Kuech TF, Dumesic JA, Huber GW (2015) Catalyst design with atomic layer deposition. ACS Catal 5:18041825. https://doi.org/10.1021/cs501862h

35. Van Bui H, Grillo F, van Ommen JR (2017) Atomic and molecular layer deposition: off the beaten track. Chem Commun 53:4571. https://doi.org/10.1039/c6cc05568k

36. Singh JA, Yang NY, Bent SF (2017) Nanoengineering heterogeneous catalysts by atomic layer deposition. Annu Rev Chem Biomol Eng 8:41-62. https://doi.org/10.1146/annurev-chemb ioeng-060816-101547

37. Strempel VE, Naumann d'Alnoncourt R, Driess M, Rosowski F (2017) Atomic layer deposition on porous powders with in situ gravimetric monitoring in a fixed bed reactor setup. Rev Sci Inst 88:074102. https://doi.org/10.1063/1.4992023

38. Cao K, Cai J, Liu X, Chen R (2018) Review article: catalysts design and synthesis via selective atomic layer deposition. J Vac Sci Technol A 36:010801. https://doi.org/10.1116/1.5000587

39. Onn TM, Küngas R, Fornasiero P, Huang K, Gorte RJ (2018) Atomic layer deposition on porous materials: problems with conventional approaches to catalyst and fuel cell electrode preparation. Inorganics 6:34. https://doi.org/10.3390/inorganics 6010034

40. Yakovlev SV, Malygin AA, Koltsov SI, Aleskovskii VB, Chesnokov Yu G, Protodyakonov IO (1979) Mathematical model of molecular layering with the aid of a fluidized bed. J Appl Chem USSR 52:959-963 (Zh Prikl Khim 52:1007-1011)

41. Suvanto M, Räty J, Pakkanen TA (1999) Carbonyl-precursorbased $\mathrm{W} / \mathrm{Al}_{2} \mathrm{O}_{3}$ and $\mathrm{CoW} / \mathrm{Al}_{2} \mathrm{O}_{3}$ catalysts: characterization by temperature-programmed methods. Catal Lett 62:21-27. https ://doi.org/10.1023/A:1019030518532
42. Suvanto S, Pakkanen TA, Backman L (1999) Controlled deposition of $\mathrm{Co}_{2}(\mathrm{CO})_{8}$ on silica in a fluidized bed reactor: IR, chemisorption and decomposition studies. Appl Catal A 177:25-36. https://doi.org/10.1016/S0926-860X(98)00253-1

43. Cavanagh AS, Wilson CA, Weimer AW, George SM (1999) Atomic layer deposition on gram quantities of multi-walled carbon nanotubes. Nanotechnology 20:255602. https://doi. org/10.1088/0957-4484/20/25/255602

44. Longrie D, Dedytche D, Detavernier C (2013) Reactor concepts for atomic layer deposition on agitated particles: a review. J Vac Sci Technol A 32:010802. https://doi.org/10.1116/1.4851676

45. Munnik P, de Jongh PE, de Jong KP (2015) Recent developments in the synthesis of supported catalysts. Chem Rev 115:6687-6718. https://doi.org/10.1021/cr500486u

46. Chan FL, Tanksale A (2014) Review of recent developments in Ni-based catalysts for biomass gasification. Renew Sustain Energy Rev 38:428-438. https://doi.org/10.1016/j. rser.2014.06.011

47. Vogt C, Groeneveld E, Kamsma G, Nachtegaal M, Lu L, Kiely CJ, Berben PH, Meirer F, Weckhuysen BM (2018) Unravelling structure sensitivity in $\mathrm{CO}_{2}$ hydrogenation over nickel. Nat Catal 1:127-134. https://doi.org/10.1038/s41929-017-0016-y

48. Coronado I, Pitínová M, Karinen R, Reinikainen M, Puurunen RL, Lehtonen J (2018) Aqueous-phase reforming of FischerTropsch alcohols over nickel-based catalysts to produce hydrogen: product distribution and reaction pathways. Appl Catal A 567:112-121. https://doi.org/10.1016/j.apcata.2018.09.013

49. Jung KT, Bell AT (2000) The effects of synthesis and pretreatment conditions on the bulk structure and surface properties of zirconia. J Mol Catal A 163:27-42. https://doi.org/10.1016/ S1381-1169(00)00397-6

50. Suntola T (1996) Surface chemistry of materials deposition at atomic layer level. Appl Surf Sci 100/101:391-398. https://doi. org/10.1016/0169-4332(96)00306-6

51. Seim H, Mölsä H, Nieminen M, Fjellvåg H, Niinistö L (1997) Deposition of $\mathrm{LaNiO}_{3}$ thin films in an atomic layer epitaxy reactor. J Mater Chem 7:449-454. https://doi.org/10.1039/A6063 $16 \mathrm{~K}$

52. Lindahl E, Ottosson M, Carlsson J-O (2009) Atomic Layer Deposition of $\mathrm{NiO}$ by the $\mathrm{Ni}(\text { thd })_{2} / \mathrm{H}_{2} \mathrm{O}$ Precursor Combination. Chem Vap Depos 15:186-191. https://doi.org/10.1002/ cvde. 200906762

53. Hagen DJ, Tripathi TS, Karppinen M (2017) Atomic layer deposition of nickel-cobalt spinel thin films. Dalton Trans 46:47964805. https://doi.org/10.1039/C7DT00512A

54. Hammond GS, Nonhebel DC, Wu CHS (1963) Chelates of $\beta$-diketones. V. Preparation and properties of chelates containing sterically hindered ligands. Inorg Chem 2:73-76. https://doi. org/10.1021/ic50005a021

55. Brunauer S, Emmett PH, Teller E (1938) Adsorption of gases in multimolecular layers. J Am Chem Soc 60:309-319. https:// doi.org/10.1021/ja01269a023

56. Barrett EP, Joyner LG, Halenda PP (1951) The determination of pore volume and area distributions in porous substances. I. Computations from nitrogen isotherms. J Am Chem Soc 73:373-380. https://doi.org/10.1021/ja01145a126

57. Lowell S, Shields JE, Thomas MA, Thommes M (2004) Characterization of porous solids and powders: surface area, pore size and density, (ed) Brain Scarlett. Springer, New York. https ://doi.org/10.1007/978-1-4020-2303-3

58. Biesinger MC, Payne BP, Lau LWM, Gerson A, Smart RSC (2009) X-ray photoelectron spectroscopic chemical state quantification of mixed nickel metal, oxide and hydroxide systems. Surf Interface Anal 41:324-332. https://doi.org/10.1002/ sia.3026 
59. Viinikainen T, Rönkkönen H, Bradshaw H, Stephenson H, Airaksinen S, Reinikainen M, Simell P, Krause O (2009) Acidic and basic surface sites of zirconia-based biomass gasification gas clean-up catalysts. Appl Catal A 362:169-177. https://doi. org/10.1016/j.apcata.2009.04.037

60. Guglielminotti E (1990) Infrared study of syngas adsorption on zirconia. Langmuir 6:1455-1460. https://doi.org/10.1021/la000 $99 \mathrm{a} 005$

61. Nakamoto K, McCarthy PJ, Martell AE (1961) Infrared spectra of metal chelate compounds. III. Infrared spectra of acetylacetonates of divalent metals. J Am Chem Soc 83:1272-1276

62. Korhonen ST, Bañares MA, Fierro JLG, Krause AOI (2007)

Adsorption of methanol as a probe for surface characteristics of zirconia-, alumina-, and zirconia/alumina-supported chromia catalysts. Catal Today 126:235-247. https://doi.org/10.1016/j. cattod.2007.01.008

63. Vuori H, Lindblad M, Krause AOI (2006) Preparation of noble metal catalysts by atomic layer deposition: FTIR studies. Stud Surf Sci Catal 162:505-512. https://doi.org/10.1016/S0167 -2991(06)80946-8

Publisher's Note Springer Nature remains neutral with regard to jurisdictional claims in published maps and institutional affiliations. 